\title{
Comments
}

\section{THE REALITY OF PROSECUTORIAL DISCRETION: COMMENTS ON A GERMAN MONOGRAPH*}

\section{Mirjan Damaska**}

Prosecutorial discretion no longer reigns supreme in American criminal justice: increasingly demands are made that discretion be confined. In search of inspiration for reform some Americans have turned their views to continental Europe, attracted by reports that prosecutors there are closely supervised in their charging decisions. Of special interest was the puzzling information that, in some European countries, prosecutors are legally bound to prosecute all serious crimes that come to their attention. This system of mandatory prosecution has been studied in its West German variant more than any other (the so-called Legalitatsprinzip) but no consensus arose as to its practical effect on the charging process. As so often happens when one looks through the transforming screen separating different legal cultures, not only does information vary with different cross-cultural reports but the same information is differently interpreted. The Legalitatsprinzip is sometimes assigned to the level of the symbolic and the exhorative, other times to the sphere of the "operational." While some claim that tight control over German public prosecutors is a "myth," others maintain that the idea of mandatory prosecution is reflected in actual practice, signaling an important difference betwen the two systems of criminal justice. ${ }^{1}$ In some aspects the ensuing controversy is reminiscent of the lively debates about what counts as reality conducted between Don Quixote, over-aware of the loftier sides of things, and Sancho Panza, sensitized to the practical.

Weigend's is an engaging and instructive book on the freedom the West German prosecutor has in the charging process, written by a German lawyer with considerable American experience. While addressing himself to the German audience, he is aware of Ameri-

* Thomas Weigend, Anklagepficht und Ermessen. Die Stellung des Staatsanwalts zwischen Legalitats-und Opportunitatsprinzip nach deutschen und amerikanischen Recht. Baden-Baden: Nomos, 1978. Pp. 203.

** Member, Board of Editors.

1. See the exchange between Langbein and Weinreb on one side and Goldstein and Marcus on the other: 87 Yale L. J. 1549-1578 (1978). Although the polemic encompassed broader issues than Legalitutsprinzip, the reality of prosecutorial discretion was one of the prominent issues in the controversy. 
can concerns and looks at the prosecutor through glasses familiar to Americans. Moving between two legal cultures, he challenges some customary approaches of his countrymen to Legalitatsprinzip as parochial, maintaining all the time a critical distance from the United States. Not only is his monograph capable of illuminating the relationship between fact and theory in the German charging process, but it is also an interesting example of the two-way migratin of legal ideas across the Atlantic.

\section{I}

The book opens with a conceptual prelude discussing the modern interpretation of two principles constructed by continental scholars as alternative models for the charging process. One is the principle of mandatory prosecution mentioned before (Legalitatsprinzip), the other is the principle of expediency (Opportunitätsprinzip). Observing the former in terms of its relationship to the prosecutor's freedom of decisionmaking, the author suggests, rightly I think, that even definitionally it does not exclude some elements involved in "prosecutorial discretion" as Americans understand it. The duty to press charges under this principle arises only after the prosecutor has satisfied himself that there is provable criminal liability in a particular case. Ascertaining "provable liability" encompasses two categories of issues, both requiring subtle evaluations: one pertains to evidentiary questions; the other to substantive criminal law. Under the first, the prosecutor weighs both the cognitive potential of evidence and its admissibility, and assesses the probability of conviction. Under the second he considers whether the alleged conduct satisfies the requirements of criminal liability.

The Opportunitatsprinzip governs where the prosecutor, having persuaded himself of provable liability, can still refuse to prosecute on what Continental lawyers call "expediency grounds" (e.g., triviality of the offense, low culpability, danger to foreign relations, etc.). Americans would refer to dispensation from prosecution on "equitable" grounds and for pragmatic systemic reasons. But it must immediately be noted that the determination of "inexpediency" of prosecution is far removed from free and unchecked dispensation. The decision not to press charges or dismiss them must be based on what Max Weber would have termed "rationally discussable" grounds. It is at the minimum subject to review by institutional superiors, a review that goes quite far up the prosecutorial hierarchy in some continental European countries. ${ }^{2}$ Clearly, then, the opposition of the two principles does not imply the juxtaposition of two radically different charging models ranging from some sort of legal automatism at one pole to free movement in a legal vacuum at

2. Throughout his book Weigend has little to say on internal compliance inducing mechanisms in German prosecutors' offices. Addressing himself to German lawyers, he takes institutional frameworks as given, and the focus of his interest is, as we shall see, on judicial supervision of discretion. 
the other. Both assume the need for the prosecutor to exercise judgment (the refusal to press charges for lack of "provable liability" is not a departure from Legalitatsprinzip), but this exercise of judgment is related to a wider or narrower range of subject matter.

Weigend's conceptual analysis, followed by many Continentals outside Germany, permits an American reader to draw an easy lesson in comparative law. With the two theoretical constructs so defined, it becomes obvious that a mere statutory proclamation in a continental system of criminal justice that it espouses one principle rather than the other tells a common lawyer very little about the degree of leeway continental prosecutors enjoy in the charging process. It is clearly possible, for instance, that prosecutors acting under a particular variant of Opportunitatsprinzip are more constrained in charging decisions than those acting under a variant of the Legalitätsprinzip. Imagine that under the former the expediency of dismissing charges is subject to stringent review and that similar mechanisms of control apply to the prior question of legal sufficiency of charges. Although Opportunitätsprinzip has been proclaimed, prosecutorial discretion is confined. Turning now to the Legalitatsprinzip, it is easy to imagine a variant form permitting great prosecutorial freedom in defining relevant situations. Neglecting the room for maneuvre offered by evidentiary questions, it is worth recalling the changing nature of substantive criminal law, a problem so often overlooked in the controversy over the practical "bite" of Legalitatsprinzip. If substantive doctrines and crime definitions are soft-edged, ascertaining whether a happening constitutes a crime may involve a great deal of flexible prosecutorial judgment before the duty to press charges becomes operative. ${ }^{3}$ There may also be a great deal of leeway in deciding how many charges to "squeeze" out of an event. And where the substantive criminal law recognizes refined exemptions from liability, the prosecutor can engage in subtle judgments quite difficult to supervise effectively, all under the pretext of checking whether legal conditions exist that trigger the Legalitatsprinzip. Briefly then, if a common lawyer looks at the continental systems of prosecution and finds that one country embraces Opportunitatsprinzip and another Legalitatsprinzip, he has as yet learned next to nothing about the process of

3. An extreme example is furnished by those Eastern European countries that espouse Legalitatsprinzip while incorporating "social dangerousness" in their concept of crime. For conduct to become criminal it does not sufflce that it satisfies formal prerequisites of criminality (e.g., falling within a penal sttute). It must also be "socially dangerous" to a significant degree: e.g., art. 7(2) Criminal Code of RSFSR; art. 8 Yugoslav Federal Criminal Code. In the classical criminal law of the West, matters determinative of insignificant danger do not affect the existence of criminality but are clearly relevant to the problem of whether it is "expedient" to press legally sufficient charges. What this shows is that exactly the same questions are in some systems relevant to establish whether prerequisites for Legalitatsprinzip exist, while in others they are addressed by prosecutors to determine whether it makes sense to proceed on legally sufficient charges. Other things remaining equal, it is possible that principles change while the degree of prosecutorial discretion remains the same. 
prosecutorial discretion in the two countries. From his perspective both may fall within the same classificatory niche. Whether this is actually the case must await discussion of factors that actually confine discretion. For the moment I must return to Weigend's book.

\section{II}

Having analyzed the meaning attributed by continental scholarship to the two theoretical constructs, the author takes us on a tour of West German regulation embodying the two principles. The original 19 th century statutory scheme was very rigid, mandating full prosecution without any exceptions, but its subsequent history is one of gradual relaxation. It is presently a mixture of the two principles in which the flavor of mandatory prosecution prevails. For the prosecution of the most serious class of offenses under German law (Verbrechen) the scheme demands that all provable crime be charged, with only a few exceptions of minor significance. As regards misdemeanors, the applicability of Legalitatsprinzip is only "assumed" in normal cases. But where the prosecutor finds low culpability or public interest in non-prosecution, he is not duty-bound to press charges. Practically then, the regime for misdemeanors can hardly be distinguished from explicit recognition of Opportunitätsprinzip. Where mandatory prosecution applies (but not where its application is only assumed), the prosecutor's decision not to press charges may be challenged in court by the victim (Klageerzwingungsverfahren), and his decision to drop formally preferred charges is with minor exceptions subject to leave of court. A large class of petty infractions is removed by statutory fiat from the domain of crime properly speaking and is processed without the participation of public prosecutors. ${ }^{4}$

If taken seriously, is this statutory regulation not quixotic on its face? The American reader may be inclined to think so: the impossible is demanded from prosecutors. Weigend does not directly address this question. It can be inferred, however, from his scattered remarks on the infrequency with which German prosecutors manipulate the statutory scheme, that he does not find the regulation quixotic. His argument is worth piecing together.

Weigend suggests that in cases of provable serious crime, German prosecutors feel impelled to press charges. Apparently the increase of most serious offenses has not been so dramatic that heavy

4. For details of the German statutory scheme see Langbein, "Controlling Prosecutorial Discretion in Germany," 41 U. Chi. L. Rev. 439 (1974). It should perhaps be added that in its German variant the Legalitatsprinzip has a special twist. Prosecutors are not only required to formally charge provable crime, but must also order police enquiries (or inquire themselves having received credible crime reports) with the view to ascertaining whether legal prerequisites exist to prefer formal charges. In German (as well as in most continental) practice most crime reports reach the police first, so that they, although legally bound to inquire, have the practical opportunity to screen criminal complaints. Prosecutors themselves conduct investigations very rarely. 
caseloads cannot be managed without a great deal of screening. The rise in the volume of crime has been accompanied by an increase in the staff of prosecutorial offices. ${ }^{5}$ The finely shaded substantive law pertaining to serious crime, purged of archaic penal statutes, leaves only a negligible number of instances where the reach of criminal legislation must be "corrected" in a particular case. Instead, prosecutors can claim that, in the case, no crime has been committed under substantive law. Nor is there need to give criminals formal grants of immunity from prosecution because of otherwise insuperable evidentiary barriers.

For misdemeanors, it will be remembered, Legalitatsprinzip is only assumed as a rule from which there are exceptions. Nevertheless, one would expect the influx of minor crime into the system to be so considerable that screening above the threshold of triviality would become the normal disposition. But the magnitude of caseload pressure must be assessed against the background of the relegation by Germans of petty infractions to a channel in which they are processed without prosecutorial participation. Nor should it be forgotten that crimes committed by minors-and juvenilia crowd statistics of crime-are not governed by the principle of mandatory prosecution. ${ }^{6}$ With respect to the remaining offenses, Weigend brings out a low-visibility factor mitigating temptations to save time by dismissing provable charges. The decision not to prosecute must in Germany be accompanied by a statement of written reasons. In the misdemeanor area, the most common alternative to discontinuing prosecution of provable charges is a special summary procedure, the so-called "penal order" proceedings. The prosecutor drafts an order that the defendant, on account of such and such offense, pay such and such fine. Unless opposed by the latter, the order becomes final and obviates the need for a trial. ${ }^{7}$ The time saved by prosecutors if they choose dismissal over its penal-order alternative is thus not so considerable as to create serious incentives to dismiss provable misdemeanors.

All this notwithstanding, a skeptic may still suspect that so much screening actually goes on that the "assumed" principle is reduced to a chimera. This additional screening may be undertaken by the police rather than by the more "legalistic" prosecutorial staff. In fact, Weigends' meticulous book contains references to sources claiming that the West German police actually screen charges, no matter that they too are formally bound to investigate and forward to the prosecutor all credible indications of crime. ${ }^{8}$ If this is true, as

5. Weigend $45-46$.

6. Weigend does not consider juvenile delinquency in his book. And the American debate on Legalitatsprinzip has largely failed to consider this area of continental criminal justice where many usual Rechtsstaat guarantees are weakened or inapplicable, and where "discretionary" decisionmaking is more pronounced than in proceedings involving adults.

7. For details on "penal order" see Langbein, supra n. 4 at 455-458.

8. See e.g., Weigend, n. 149; also at p. 41 in fine and 75 in fine. 
this reviewer knows it to be in similar systems, a credible case has been made for the proposition that there is little need for German prosecutors to manipulate the procedural regulation. The influx of cases to prosecutors is kept at levels compatible with the tenability of the ideal of full prosecution. Substantive law is finely shaded and permits of some "screening" at the substantive level. And the statutory scheme is predicated on the realistic insight that the more serious a crime the less acceptable the failure by prosecutors to press provable charges.

\section{III}

Even if there are in Germany no practical pressures rendering the statutory scheme clearly illusory, this circumstance reveals little about its impact on actual goings-on in the administration of criminal law. In fact, it can be doubted that the scheme per se would be capable of inducing prosecutors to comply with the dominant idea that all provable crime should be prosecuted. As we noted before, ascertaining both the "provability" and the "criminality" of a happening calls for subtle and complex judgments exceedingly difficult to supervise effectively. Charges can be made to appear "legally" insufficient whenever prosecutors find it "expedient" not to prosecute provable crime. There are passages in Weigend that seem to suggest just that. At one place he likens the German statutory scheme to a corset whose strings can easily be loosened by prosecutors to reach an outcome thought desirable on independent grounds. ${ }^{9}$ And the last part of the book is, as we shall see, a search for effective mechanisms to confine prosecutorial freedom in charging. Should this be taken to mean that the statutory scheme per se has no practical impact? Weigend seems to vacillate on this point. In his first skirmish with realities of prosecutorial conduct he reviews some recent German studies exploring prosecutorial attitudes to the Legalitätsprinzip. These studies indicate that prosecutors profess to feel bound to prosecute provable charges not only when they must, but also when they might have departed from the "assumed" Legalitatsprinzip. ${ }^{10}$ Somewhat optimistic about what attitudinal research tells us about actuality, Weigend suggests that Legalitatsprinzip "dominates" charging practice and guides prosecutors in their daily work; although there is room for evasion, the ideal of full prosecution exercises a hold. ${ }^{11}$ On the other hand, as we shall see, one of the recurring themes of the book is the "debunking" of the principle of mandatory prosecution. And there are passages where the impor-

9. See Weigend 160.

10. Weigend's main source is the study by Blankenburg, Sessar \& Steffen, Die Staatsanwaltschaft im Prozess strafrechtlicher Sozialkontrolle (1978). For summary see Weigend 23-24. Similar findings were reported as following from interviews by Goldstein \& Marcus, "The Myth of Judicial Supervision in Three 'Inquisitorial Systems', " 87 Yale L. J. 240, 275 (1977).

11. Weigend 24 and 61. 
tance of choosing one principle or another per se is disparaged. ${ }^{12}$ Before we turn to mechanisms more obviously capable of confining prosecutorial freedom in the charging process, the possible independent impact of Legalitatsprinzip is worth exploring. Why would prosecutors deceive others or themselves in claiming allegiance to the ideal of full prosecution?

One begins to understand the expressed deference to Legalitatsprinzip as one reads Weigend's historical sketch tracing the origin of the principle in German legislation and its subsequent fortunes up to the present day. Here conventional German accounts are followed. The victory is linked to mistrust of prosecutorial offices in some German lands during the turbulent years of 1848-1849. More generally, liberal ideology is considered as a potent explanatory factor. ${ }^{13}$ While a mere reference to liberalism may suffice for the German reader, an American may be left to wonder what liberal ideology has to do with Legalitatsprinzip. What the author has in mind, of course, is a special brand of continental liberalism, quite different from its Anglo-American variants. It is part of this ideology that the statutory norm, interpreted without intrusion of politics, according to a formal science of law, is the primary guarantee against state interference with the administration of justice. Criminal law should be administered by general rules and the later must not be softened by the "dumb goddess" of equity. ${ }^{14}$ Charging decisions, too, should never be grounded on equitable or policy reasons, but remain solely a matter of legal sufficiency.

There is yet another consideration the American reader must bear in mind. At the time when Legalitatsprinzip found its way into German legislation, it was traditional to regard the institution of criminal proceedings as a decision involving correct subsumption under legal categories. The inquisitorial judge who was entrusted with that decision was considered bound to commence criminal proceedings whenever legally prescribed fundamenta inquisitionis were met. The power to show mercy and fail to launch proceedings was denied to the judicial bureaucracy. When, after the mid-nineteenth century reforms, prosecutorial function was separated from judicial, the old arrangement continued to show through in the design of the charging process. The contrast with the English tradition is striking. Here administration of criminal law was not in the hands of legal professionals, but mainly in the hands of the local elite. The undifferentiated power to show mercy runs through the judicial system from top to bottom. Quite naturally, then, it seemed alien to officials in the system to imagine criminal-procedural decisions as a legal-technical matter. And it should not surprise us that

12. See e.g., Weigend 168, where West Germans are chastized for their theoretical and abstract discussion of merits and demerits of charging principles, while Americans are praised for their practical concerns. See also id. 172.

13. Weigend 29.

14. The phrase is by Kant (The Philosophy of Law 5) (1887) whose views importantly influenced the Rechtsstaat idea. 
even contemporary solutions and attitudes still show the memory of those ancient arrangements. ${ }^{15}$

It was pointed out before that the original German statutory scheme was very rigid but its subsequent history one of gradual relaxation. Weigend finds the main reason for this relaxation in the increased legitimacy of prosecutors, helped, paradoxically, by the apolitical nimbus of the Legalitätsprinzip. But surely this can be only part of a more complex story. Observe how the ideological underpinnings of the principle came to be so greatly eroded in our century. The move toward the welfare state was accompanied by a new approach to crime, emphasizing social policy at the expense of legal considerations, with attitudes toward crime committed by minors often playing the role of the Trojan horse in the citadel of the classic legal system. Nor should one overlook how the discovery of extranormative factors in legal decision-making undermined old conceptions that criminal justice could function by applying a fixed normative program. Whether the most recent skepticism in some

15. The peculiarly English structure of political authority takes us quite a distance towards explaining the large discretionary powers of American public prosecutors. Langbein has recently advanced the thesis that this phenomenon is due to the tenacious tradition of private prosecution in England. The American public prosecutor stepped into the shoes of the private prosecutor who obviously freely decides whether to go to court. See Langbein, "Understanding the Short History of Plea-Bargaining," 13 Law \& Soc. Rev. 361, 267 (1979). From a broader comparative vantage, I think, the adjective "private" for English prosecutions must be taken with a grain of salt. What was so characteristic of English government was that officials and citizens indiscriminately engaged in private and public affairs, so that the borderline between public and private was much less certain than it later appeared to 19th century historiography.

Consider the following interpretations of otherwise known events. Following the centripetal tendencies of the 12th century, prosecution by the victim as a party atrophied not only on the Continent but also in England: "criminal appeals" became a rarity, and the Crown could take over prosecution from an unwilling appellant. Official bodies or individual officials actually decided about institution of criminal prosecutions proper. It is true that in Tudor times information by citizens (and qui tam actions) gained currency, especially in the sphere of lesser crime; also that victims remained active in criminal trials. But was the victim a "party" to a "private" prosecution? Technically, of course, proceedings were wholly or in part on behalf of the Crown. More importantly the activity of the victim in England came very close to what the victims were doing in the different setting of the continental inquisitorial process as "informers" and as "witnesses." Reading, as many 19th century historians did, a dominus litis character into the victim's role may well be anachronistic.

Officials who actually determined the "life" of the prosecution were not legal professionals and their decisions escaped legal categories. Viewing the institution of proceedings as a technical-legal matter was totally alien to them. And it is this attitude that survives in the American public prosecutor.

Continental systems of the corresponding period more clearly differentiated between official prosecution and that by a victim as a party. And while the latter greatly atrophied in German lands, it remained an ideal, a form of proceedings legally superior to the inquisitorial process until the late 18th century. See e.g., for late 18th century German lands, Homberk zu Vack, "De diversa indole processus inquisitori et accusatorii," in Platt, Analecta Juris Criminalis, 398 (Francoforti et Lipsiae 1791). Criminal prosecution, by the victim in various forms, survives in continental Europe to the present day. 
German academic writing about the practical significance of Legalitätsprinzip-the skepticism that makes Weigend vacillate-has something to do with the apostatic courtship by younger scholars of ideas with American provenance is an interesting question deserving of attention by those who study the migration of legal ideas.

Even if weakened, however, the idea of limiting prosecutorial freedom solely to matters of legal sufficiency seems still very much alive. In fact, much of Weigend's book can be viewed as a testimony to this effect. Whole sections try to debunk the exaggerated beliefs as to the importance, or even "indispensability" of Legalitätsprinzip for a policy devoted to the rule of law. ${ }^{16}$ A large detour on the American system of prosecution purports to show by counter-example that devotion to freedom is not incompatible with vast discretionary powers vested in monopolistic public prosecutors. ${ }^{17}$ An important section of the monograph attacks the view that Legalitätsprinzip is enshrined in paragraphs of the West German Constitution dealing with classic Rechtsstaat guarantees. ${ }^{18}$ Unless faith in the importance of mandatory prosecution was still live and kicking, or unless Weigend was attacking straw men, all these important sections of the book would make no sense. It is true that, to a casual American reader, many of the opinions Weigend sets out to undermine or destroy appear parochial or amusingly naive in their reliance on paper guarantees. But the more sophisticated are likely to suspect that they are confronted here with aspects of a legal culture whose continuing hold may be deeper precisely because unreflectively accepted as part of tradition. And he may even begin to wonder how much in their landscape of reference may appear similarly ludicrous or incredible to an outsider.

It is notoriously difficult to establish the independent effect of a legal ideal on actual decision-making. But if the supporting ideology is not dead, at least a subtle influence cannot safely be ruled out. Pragmatic reasons favoring dismissal of provable charges may encounter more counter-pressure when the ideal of full prosecution is written into the law. The temptation to accept pragmatic pressures could be somewhat reduced. If some such subtle influence of the ideal is posited, the reluctance of German prosecutors to dismiss provable misdemeanor charges on grounds of "equity" or especially public policy becomes explainable. Such grounds are viewed as a departure from an ideal, or as a "second best" solution. ${ }^{19}$ Even

16. See Weigend 63-88.

17. From its inception the Legalitatsprinzip was regarded as a necessary "corrective" to the monopoly of public prosecutors. An alternative was the subsidiary right of the victim to trigger criminal prosecutions. See infra n. 37.

18. See Weigend 70-78.

19. Legalitatsprinzip makes more sense to most American lawyers if explained as a regulating ideal rather than as an outcome determinative. rule: cf. Goldstein \& Marcus, supra n. 10 at 282. But even if viewed as such an ideal, it can hardly generate much enthusiasm among American lawyers. They generally seem less exercised by overarching schemes and ideals as preconditions for useful action than traditional continental lawyers. Great concern with ideals may in their opinion obfuscate clear 
Sancho Panza, infected toward the end of his adventures by the impotent dreams of the errant knight, becomes less ready to accept things just because they happen than he was when he set out from La Mancha.

\section{IV}

Though muted, the theme of whether the German statutory scheme makes a practical difference reverberates through Weigend's chapter on American prosecutors. His lengthy comparative law excursus is meant to suggest that essentially similar problems confront prosecutors in enforcing criminal law, problems which transcend important differences in institutional framework, the structure of proceedings, and conceptions of proper prosecutorial function. Following an analysis of some American statistical data, he attempts to show that refusals by prosecutors to press charges display a "surprisingly" similar pattern, although one system expresses allegiance to the principle of mandatory prosecution whereas the other finds selective enforcement both necessary and desirable. In West Germany as in the United States failure to prosecute (with variation depending on crime type) is mainly justified on grounds of insufficient proof. As in both countries equitable and pragmatic reasons for not pressing provable charges are advanced mainly in the sphere of less serious crime..$^{20}$ The purpose of the comparative detour is clear. Weigend intends to score further points in "desublimating" the traditionally revered Legalitatsprinzip.

Where the two prosecutorial systems are compared by using a measure as crude as the broad tendency to which the author refers, the parallelism he detects seems hardly surprising. Is it not reasonable to expect that prosecutors everywhere find it easier not to press provable charges of less serious offenses than really serious crime? But, in focusing on a similarity so general, important differences become blurred. Subtle divergences in the charging process, such as those attributable to the impact of ideology, quite obviously cannot be captured. And in the light of the current American debate on how different the continental prosecutorial system is from the domestic one, some of these differences should be brought out. (I should hasten to add that most data on which I shall rely to suggest

analysis of real life problems. Especially of late they seem to be drawn to questions of the "optimal" rather than the "ideal." What is in the center of their attention is the search for the correct scale of law enforcement in view of scarce resources (and some other constraints on full enforcement.) See however the thoughtful remarks by Packer, The Limits of the Criminal Sanction 286 (1968).

For a German source of skepticism as to full enforcement see Popitz, Praeventivwirkung des Nichtswissens (1968). See Weigend's critique thereof at 46-48.

20. See Weigend 160,168 for summary and discussion of statistics. Partially the same statistics have been used and similar conclusions reached for the U.S. by Reiss, "Public Prosecutors and Criminal Prosecution in the USA," 1975 Jurid. Rev. (Scotland) $1,13-15$ (1975). 
the remaining contrasts can be found, scattered, in Weigend's description for his German audience of American prosecutorial offices.)

In the absence of reliable comparative statistics, I find it plausible to expect that within the contours of the broad parallelism American prosecutors more frequently refuse to press charges of provable crime than do their German colleagues. Consider "equitable" grounds for dispensation first. With all due reservations against robust statements, I hope that cognoscenti would agree that the American substantive criminal law contains more antiquarian and overlapping statutes, and that it is less subtly nuanced than the German. If so, it stands to reason that there is greater need to "correct" over-reaching penal statutes in the U.S. than in Germany. While it is true that "equitable dispensation" may occur at various levels of the process (including jury nullification), it is surely convenient to let the Cerberus at the gate of the system also exercise this dispensation. ${ }^{21}$

Turning to pragmatic public policy reasons for not pressing provable charges, the divergence between the two systems may easily be more striking. This probably holds even if one assumes (without conceding) that transaction costs of criminal justice are equal, that docket-pressure is the same, and that, with serious crime, large absolute numbers are not involved. Winds of change notwithstanding, practical motives, reciprocities of cost and benefit, bargaining and compromise, all these paraphernalia of what Dewey called "trafficking ethics," are still much more firmly entrenched in American than in German administration of criminal justice. ${ }^{22}$ Telling illustrations are different reactions in the two countries to informal grants

21. For the sake of brevity the text deals solely with the decision whether charges should be filed or not. But discretion is also exercised in regard to the question how many and precisely what charges should be filed. In the non-adversary German process the prosecutor has less control over charges than his American colleague. The accusatory pleadings of the former merely define the factual parameters of the event within which the court independently proceeds to the legal characterization of the occurrence. The prosecutorial legal characterization is not binding. However, it would be wrong to imagine that German prosecutors have no flexibility with respect to the number of crimes they charge (See $\S 154$ of the German Code of Criminal Procedure for an example), or that they do not sometimes set factual parameters so as to create a "charging down" which the court cannot bring up to the level corresponding to what actually happened.

22. See Dewey, German Philosphy and Politics 57-8 (1915). Dewey favored, of course, such ethic to the "unsullied" moral idealism evoking to his mind blind and ferocious deontism which refuses to test values against reality. From the continental (not only German) vision, however, pragmatism was (and often remains) almost a dirty word, similar in meaning to opportunism.

The winds of change referred to in the text concern the ever increasing involvement of German social scientists with the actual operation of criminal justice systems, creating tensions with traditional dogmatic analysis: will the old system stand the test of reality? In theory new perspectives opened up. The opus of Niklas Luhmann introduced German procedural thinking to a variant of system-analysis, and some younger scholars seem to be propagating the recently fashionable public policy analysis. See e.g., Walde, Juristische Folgenorientierung (1979). 
of immunity and to bargaining with charges in the area of serious crime. It is true that Americans are of two minds about these practices, but they are at least tolerated. In Germany one finds only timid equivalents, mainly for lesser crime, and such practices are still widely regarded almost as scandalous and demeaning to the administration of justice. ${ }^{23}$

Another significant difference is latent in the broad parallelism. The refusal to file charges on the ground of evidential insufficiency is predicated on quite different judgments in the two systems. The problem cannot be treated fully and a few examples offered $a$ la diable must suffice. Predicting whether cognitively compelling information will pass through the legal screen of admissibility is a much more difficult and uncertain undertaking in America than in Germany. Although West Germans have developed what are by continental standards quite elaborate admissibility rules (Beweisverbote), there is still in actual practice much less discrepancy between what is known and what can be proved than in the contemporary American criminal process. ${ }^{24}$ Assessing the probability of conviction is in West Germany still mainly a question of evaluating the cognitive potential of available information. Nor is it necessary for the German prosecutor in predicting the outcome to consider such elusive variables as the reaction of the jury to charges, especially in view of the unanimity requirement. German lay assessors decide jointly with professional judges on both liability and sentence, and they are generally more predictable than the inscrutable jurors. For these and other reasons it seems fair to say that it is much harder for the American prosecutor to decide whether there is enough evidence to go to court or whether more serious charges should be filed. As a result of this greater complexity, the decision not to prosecute is not easily subjected to effective review. In this connection the different procedural context of the adversary and non-adversary process should not be forgotten. In the adversary procedure the prosecutor normally refuses to file charges unless he is reasonably certain of conviction; he is out to win. Forcing him to prosecute malgré coeur, while not unprecedented, places a severe strain on normal adversary arrangements. In the setting of the nonadversary process with its more bureaucratized

23. See Weigend's passing comparative remarks on bargaining with defendants in Germany and the U.S. at 183. A mechanism with strong potential to involve German prosecutors in bargaining with offenders is the "conditional dismissal of charges" introduced in 1975 ( $\$ 153(\mathrm{a})$ of the German Criminal Procedure Code): a kind of "pre-trial diversion" in return for specific activity (such as charitable contributions) on the defendant's part. Whether developed under American influence or not, the mechanism may yet prove deeply subversive of traditional prosecutorial positions.

24. An additional reason is the difficulty in the adversary system with using noncooperative witnessers, especially the victim. Though witnesses may be compelled to testify, their testimony can easily damage the prosecution's case. Weigend observes that the problem of such witnesses is less acute in the nonadversary process (at 145), and those with practical knowledge of the two systems would, I think, agree. 
prosecutorial staff, problems take a different shape. Both in Germany and elsewhere there is authority that the prosecutor should file charges, given an initial probability that a crime has been committed, even when he has serious doubts whether the case will result in a conviction. In other words, he must go in dubio contra reum..$^{25}$ Before one dismisses this authority as just another doctrine without much practical penetration, consider that, in the differently structured continental hierarchy of prosecutors, there is little "cost" or stigma in "losing a case" if the initial quantum of evidence supported prosecution. And ordering an unwilling prosecutor to proceed causes little trouble because most procedural activity emanates from the bench anyway.

In conclusion, then, Weigend's parallelism of prosecutorial behaviour in Germany and America is not incompatible with the con. tinued existence of vast divergences in the charging process of the two countries. It is important to note that these divergences may also concern the latitude left to the prosecutors in deciding what disposition to make on the charges.

I realize that those interested in the reality of prosecutorial discretion find it easy to look at the input and output sides of the criminal justice systems, making inferences about the magnitude of discretion from high mortality rates of initially ingested cases. But such empirical research is a very poor measure of magnitudes of discretion. Suppose that research revealed a statistical identity between America and Germany in numbers of cases where prosecutors declined to press provable charges. Such equality would unveil little about whether or not prosecutors in the two countries enjoy roughly similar freedom in disposition of charges. Imagine, for example, that in two systems, an identical number of shoplifting cases were screened because of the small value of the stolen object. But while in one system the question of what is small value is left to prosecutorial intuition and made unreviewable, it is defined in the other in monetary terms with the charging decision thereupon made reviewable. ${ }^{26}$ Si duo faciunt idem, non est idem. Nor is this the end of the story. Even if decisions are reviewable everywhere, it may be important to ask whether the review is designed to assure decisional uniformity across the state or only within local prosecutorial offices. In asking these questions we touch on issues important for the reality of prosecutorial discretion.

\section{V}

Some insight into this matter can be gained in the last chapter

25. Weigend reports a German case to this effect (p. 19 n. 21). Compare also Hermann, "The Rule of Compulsory Prosecution and the Scope of Prosecutorial Discretion in Germany," 41 U. Chi. L. Rev. 468, 472 (1974).

26. With all its limitations a more promising strategy of empirical research would be an adaption of the methodology used by Kalven and Zeisel in their study of the American jury. See Kalven \& Zeisel, The American Jury 33-54, 85-103 (1966). 
of Weigend's monograph where he returns to the domestic scene from his American excursion. In the U.S. he encountered an open acknowledgement of large areas of prosecutorial freedom in charging, as well as a practically oriented debate-about mechanisms capable of reducing and supervising discretion. He faults his countrymen for their excessive penchant for theoretical dissection of the charging process and their reluctance to come to grips with practical problems of prosecutorial free play. ${ }^{27}$ Even if this free play is less than in the U.S., the absence in Germany of effective instruments of supervision is to him a cause of concern. After all, equal enforcement of penal law is at stake. He is therefore prompted in the last chapter to suggest a practically effective scheme for the confinement of prosecutorial freedom. His attention is, however, selective. He does not attack the problem of discretion in the charging process generally, but rather focuses solely on discretion to refuse provable charges. ${ }^{28}$ And taking the existing German internal institutional supervision for granted, he focuses on external control.

Let me quickly outline Weigend's scheme for judicial control. Compulsory prosecution would continue to apply for the most serious class of offenses under German law, but the prosecutor would be excused from the duty to prosecute charges in "exceptional cases." Weigend's idea is to remove the temptation to circumvent the statutory mandate in cases where the happening meets the legal prerequisites of criminality but particular circumstances do not really warrant prosecution. This, of course, constitutes an admission that such instances occur even in the finely shaded German substantive law. ${ }^{29}$ To prevent this broadly couched exception from swallowing the rule, departures from the duty to prosecute would have to be extensively justified in a written document. As under present law, the latter would then be served on the victim and he or she entitled to trigger judicial review (Klageerzwingungsverfahren).

For misdemeanors, the author would explicitly recognize the "principle of expediency" rather than timidly acknowledge it as an exception from the otherwise "assumed" Legalitatsprinzip. But the resulting general power to prosecute provable misdemeanors would have to be exercised according to specific criteria, and be subject to judicial control at the victim's insistance. Thus Klageerzwingungsverfahren would be extended from the felony into the misdemeanor area, and encompass review of grounds for disregarding provable charges. This requires, of course, that a framework first be developed within which charging decisions can be evaluated. It is accordingly crucial to Weigend's proposal that charging standards be formulated. In selecting a technique, the inspirations for the author

27. See Weigend at 168 . Similar views were expressed by Goldstein \& Marcus, supra n. 10 at 282 .

28. In other words, the author is interested in confining discretion solely where its exercise constitutes a departure from the Legalitatsprinzip.

29. See Weigend's example with robbery at 173 n. 746. For further information see now Blankenburg, Sessar \& Steffan, supra n. 10 at 262. 
were sentencing guidelines so frequently advocated in many countries nowadays. In both areas, charging and sentencing, decisions greatly depend upon circumstances of the case. Because the underlying policies are in addition frequently at cross-purposes, regulation in terms of dichotomous rules appears inappropriate. But the author is not satisfied with the most common brand of guidelines that merely point to factors to be taken into account, leaving the weight to be accorded to these factors undertermined. Desirous of establishing effective supervision, he is prepared drastically to schematize and simplify. With an eye on paradigmatic examples (Regelbeispiele), he would isolate factors to be considered in charging decisions, and classify them (on analogy with aggravating and mitigating circumstances for sentencing schemes) into those favoring and those opposing prosecution. Each factor should be assigned the same weight, and the mere numerical preponderance of one class of factors should point to a particular charging decision. In case of a draw the defendant should be given the benefit of doubt and excused from prosecution. the scheme is not as rigid and mechanical as might appear at first blush. Guidelines suggest what decisions should be reached in a "normal" case. Prosecutors would be entitled to respond to unanticipated factors, or weigh a foreseen factor differently in a special case. But such departures would come at a cost: where guidelines are followed, only a brief statement of reasons by the prosecutor is called for, and the possible judicial review should not be too penetrating. Departments, however, require extensive justification and are subject to much closer judicial scrutiny. ${ }^{30}$

Weigend doubts that acceptable guidelines could be fashioned without systematically drawing on the insights developed in prosecutorial offices over time. But to show the reader that there can be music for the instruments he has designed, he-himself not a prosecutor-tentatively and in a fragmentary fashion presents a small catalogue of factors favoring and opposing prosecution. ${ }^{31}$ This catalogue provides fascinating reading: numerous pungent questions are raised in it and the answers given bring with them the sense of larger issues. But, chemin faisant, perhaps unwittingly, he exposes the immense difficulty of working out a comprehensive set of guidelines and linking them to a compliance-inducing mechanism that involves the judiciary. Because these difficulties relate to the limits of supervising prosecutorial decisionmaking, the most important ones deserve mention.

To begin with, the "raw material" for Weigend's guidelines, i.e., the "common law" of prosecutorial offices, is worth exploring. It

30. Compare the attitude of American courts faced with a similar scheme devised for the Federal Parole Commission: Geraghty v. United States Parole Comm'n, 579 F.2d 238, 259-63 (3d Cir. 1978); Page v. United States, 428 F. Supp. 1007, 1009 (S.D. Fla. 1977).

31. See Weigend 178-92. His frequent source of reference is the Uniform Charging Standards of the California District Attorneys Association (1974). 
would seem wrong to imagine this prosecutorial knowledge to form some sort of a hidden network of rules. Much of it is probably in the form of what Kuhn has termed "shared exemplars," emerging from discussion of specific cases. ${ }^{32}$ Such exemplars are subtly betrayed when conceived as something we manage by applying criteria. They oppose methodicization and are obstinately resistant to scheme and generalizations. When captured in verbal formulae, petrified as it were, they actually perish and the need arises among practitioners to create a new "tacit knowledge." Aside from such shared exemplars, one probably finds intuitive rules of thumb, or unanalyzed customary reactions that leave complex policy issues unresolved. Here Weigend's suggestion of the similarity between sentencing and deciding on charging proves illuminating. In both areas competing goals have not been reconciled. What rehabilitative concerns suggest may run counter to felt deterrent needs or to conceptions of "just deserts." Bringing unanalyzed reactions to the surface and analyzing them for the sake of incorporation into the guidelines is quite likely to provoke great controversy. In saying so I make allowance for the possibility that German society is less ridden by controversy over values than the American. Devising a consistent penal policy is a Herculean task, especially when one is aiming, as Weigend does, not at a pleasing theoretical formula of little practical impact, but rather at an effective practical regime. All the difficulties I have mentioned so far are exacerbated if one has a preference for the statutory form of guidelines. Incorporation of whatever guidelines one manages to formulate into the procedural code only accentuates a wide divergence in the character of rules and guidelines organized around "exemplars." To fit into the "strategic vision" of a continental code, and in order to be in harmony with its parameter language, "tactical" guidelines would inevitably be pushed toward greater systematization than warranted, and toward greater generality than effective supervision favors. They could quite easily degenerate into broad proclamations, not unlike much legislation on how sentences must be determined, which would require in turn additional, non-statutory guidelines. ${ }^{33}$ And even if the German legislator is less paralyzed to enact a rational scheme than the American, it requires a leap of faith to expect him to keep abreast of the dynamism of charging standards. Weigend somewhat grudgingly opts for the legislative form, but if he intends to develop a truly effective scheme, he would probably be well advised to abandon the continental predilection for tackling all kinds of problems at the legislative level.

Another difficulty stems from Weigend's effort to confine prosecutorial discretion solely in that area where latitude in judgment constitutes an exception from Legalitatsprinzip. His guide-

32. See Kuhn, Structure of Scientific Revolutions 191 (1970).

33. Weigend (at 170-71) is aware of these problems, but sounds optimistic about the chances for their resolution. 
lines do not cover matters involved in ascertaining evidentiary sufficiency or substantive criminal law questions. And as early as his conceptual prelude, the author himself suggests that determining whether charges are adequately based in evidence and in substantive law provides for much prosecutorial flexibility. ${ }^{34}$ What can result from this narrow focus? Tightening judicial supervision of discretion in one sphere while leaving it as it is in another may invite subterranean shifts of discretion from the more to the less supervised areas. It is true that the possibility that Weigend provides for prosecutors to depart from guidelines reduces the incentive to resort to evasion. Nevertheless, the cost involved in drafting an extensive justification of the departure, coupled with the possible threat of reversal by the judge, keep the temptations for manipulation alive.

The possibility of judicial reversal of a decision not to prosecute leads me to a further point. The author wants his scheme of judicial supervision to be more than a mere rhetorical framework within which charging decisions will be discussed. He wants to develop a system that actually influences prosecutorial decisionmaking and moves it towards particular outcomes. But is his scheme, expanding the presently existing German judicial supervision, likely to turn into such a powerful discretion-confining device? At least on the basis of present experience with judicial supervision of prosecutorial decisionmaking one wonders. In Germany as well as in the U.S. one should distinguish here judicial control of initial refusal to file charges and control of subsequent efforts to drop them. The latter move requires (with minor exceptions) judicial consent in Germany, but it is routinely given and is a far cry from a powerful behavior-influencing mechanism. ${ }^{35}$ Concerning initial refusal to charge there is, of course, the Klageerzwingungsverfahren at the victim's initiative. We do not really know whether this procedure importantly confines decisions not to press charges, but one may conjecture that it makes a difference over a system where, as in America, the victim cannot challenge such prosecutorial decisions at all. On the other hand, it would be unrealistic to expect a powerful impact. The victim must bear the costs if his request for prosecution be denied, so that it causes no surprise that the Klageer-

34. Hassemer has recently argued in an incisive essay that problems of ascertaining criminal liability leave almost as much room for flexibility as problems of determining the proper sentence: "Die Formalisierung der Strafzumessungsentscheidung," 99 Z. f. gesamte Strafrechtswissenschaft 64, 86 (1978). While it may be true that prosecutors are reluctant to take advantage of the free-play left by broad substantive law provisions, their hesitancy may change. Such restraint is alleged by Hermann, supra n. 25 at 472.

Guidelines for evidentiary questions may arguably violate values behind the continental free evaluation of evidence. But the argument has little force. Those familiar with the "tacit knowledge" of prosecutorial offices realize that sporadic internal evidentiary guidelines already exist.

35. See Weigend at 54 on inefficiencies of judicial supervision in Germany. The arrangement in the American federal system is similar. 
zwingungs process is seldom seized upon by the victim. ${ }^{36}$ It may perhaps correct egregious case of arbitrariness where the chances of success for the movant are considerable. But even if the mechanism were much more frequently used other problems remain. Unable to treat the topic more fully, let me suggest only one. If one is to stimulate prosecutors to advance actual reasons for their decisions, rather than those that would "withstand" review by the judge, judicial review must be restrained. Such restraint may, however, deter the victim even if the issue of cost is differently resolved. On the other hand, if judicial review is penetrating and aggressive, the gap feared by Weigend is likely to reappear: what prosecutors say in justification and what really motivates them become increasingly divergent.

I have not dwelt on these difficulties of Weigend's proposal because I am opposed to judicial supervision of prosecutorial decisionmaking. I find myself in favor of such judicial responsibility, and the expanded Klageerzwingungs process seems to be superior to the subsidiary action by the victim as an alternative. ${ }^{37}$ Although I am much more skeptical about the effectiveness of the scheme than he is, I find even modest control of prosecutorial free-play (elimination of clear abuses of power) worthwhile. My purpose was different. By suggesting the limits of judicial review as a prosecutorial discretionconfining device, I wanted to direct the reader's attention to matters of greater importance for understanding the reality of prosecutorial discretion in Germany than are mechanisms of external control of charging decisions.

VI

An American observer interested in the latitude of German prosecutorial discretion should look inside the prosecutor's offices for his most important material. If German prosecutors have indeed less latitude in the charging process, it is primarily because of specific mechanisms and the general atmosphere generated there. At the level of local offices there are internal instructions, conferences to discuss cases in search of uniform solutions, an astonishing reliance on documentation and superior control. The fragmentary "common law" arising out of these arrangements is of course neglected by academicians because what is involved is formally not part of the legal system and is recalcitrant to ordering through conventional methods. But are not American local offices very similar?

36. Observe that in the U.S. the victim of crime can affect the decision to prosecute (e.g., by refusing to cooperate in testifying against the offender), but cannot affect the decision not to prosecute. The only remedy against prosecutorial inaction is for the court to appoint a special prosecutor or grand jury.

37. Such action by the victim is best known in its French variant. Another quite influential variation is the Subsidiaranklage developed before the turn of the century in Austria. It is now regulated by $\S \mathbf{4 8}$ of the Austrian Code of Criminal Procedure 1975. For its dissemination abroad see e.g. art. 60 of the Yugoslav Statute on Criminal Procedure 1977. 
As in so many other matters, so in regard to the internal organization of prosecutorial offices, there is in the U.S. an enormous variety of solutions. And some offices in large metropolitan areas may come quite close to what I have just said about Germany. There is, however, at least one significant difference. The head of a local German prosecutorial office should not be identified with the American chief prosecutor of a local jurisdiction. Even where the latter is not locally elected, he tends to be much more fiercely independent of superior authority and much more inclined to regard problems in his work as requiring compromise, bargaining and creative choice than is the case with his German colleague. The latter seems by comparison almost ascetic in his refusal to boldly confront policy considerations; narrowly technical, he tends to seek and try to discover "correct solutions" in terms of professional standards. In brief, no matter how dramatic some recent changes appear to a German domestic vision, he shows traces of a civil-service career mentality. ${ }^{38}$

What I have just said about local chief prosecutors affects the regularity of decisionmaking above the local level. Even if there were no hierarchial mechanisms to assure a degree of uniformity in charging over the state territority, a measure of such uniformity in Germany would spring from the spirit of professionalism, much more so than in the more political American prosecutorial apparatus. But instruments to assure hierarchial control over and above the local level do exist, although Germany seems in this respect to offer less than many other continental European sytems. For instance, German administrative law empowers citizens to complain against the decisions of chief local prosecutors to their superiors at the state level; the former cannot play the role of unreviewable local potentates. ${ }^{39}$

It is mainly for these internal reasons that the latitude of German prosecutors in the charging process is probably more confined and charging decisions more uniform than in the U.S. And the study of internal structures and incentives within the prosecutorial hierarchy may suggest to an American observer a broader conclusion. To an internal continental vision there are very significant differences among prosecutorial organizations in various European countries. But from the American vantage the differences seem to pale to relative insignificance: prosecutorial hierarchies all appear more centralized, more bureaucratized and more narrowly professional than American analogues. Whether a country, like Germany, stresses the Legalitatsprinzip, or another, like France, the Opportunitatsprinzip, is from the American perspective of little signif-

38. What I have said in the text is hardly novel. Cf. e.g., Davis, Discretionary Justice: A Preliminary Inquiry 191 (1971). Those interested in trends must realize that German bureaucracy is changing, with civil service mentality weakening. See Schmid \& Treiber, Burokratie und Politik 190-195, 223 (1975). 465-6.

39. This is the "departmental complaint" described by Langbein, supra n. 4 at 
cance in terms of realities of prosecutorial decision-making. Discretion here and discretion on the Continent remain significantly different. And in defining the difference one is tempted to take recourse to the old Weberian distinction of two kind of discretion, based on the difference between pre-bureaucratic and the bureaucratic forms of authority, a distinction which, albeit weakened in modern times, still retains something of its meaning. The broader discretion of the American prosecutor still shows traces of prebureaucratic decisionmaking, unstructured, and akin to personal dispensation by a local potentate, while continental prosecutors exercise discretion in a "rationally debatable" form. ${ }^{40}$ And if someday Americans find it necessary to develop really effective mechanisms for reducing the leeway in decision-making on charges, it may easily transpire that voluntary coordination of local offices and nonmandatory guidelines as well as judicial supervision are all insufficient. Very costly remedies in terms of political ideology-greater centralization and bureaucratization-will have to be seriously contemplated.

As suggested before, this internal perspective is largely absent from Weigend's monograph. But he cannot be faulted for it. His presentation is adjusted to the German eye and takes existing German internal prosecutorial structures for granted. But within the area of his choice, centering on improvements of judicial supervision, Weigend has written a well documented book, combining cautious scholarship with an attractive measure of conceptual audacity. In attempting to bring together traditional German approaches and modern, partly American concerns, he has on the whole successfully braved the dangers of a mixed genre. The end result is a book contributing significantly to developing a perspective in which continental and American systems of prosecution will become truly comparable.

40. See Weber, 3 Economy and Society 976-79 (1968). Observe that Weber did not regard the reign of rules associated with German bureaucrats as a sole technique of "rationalizing" discretion. He foresaw the possibility of supervising discretion in terms of calculating the utility of alternative choices. See also Eckhoff \& Jacobsen, Rationality and Responsibility 8-10 (1960). 